This is not the version of record. The full version of González-López, Irene (2018) Marketing the panpan in Japanese popular culture : youth, sexuality, and power. U.S.-Japan Women's Journal, 54, pp. 29-51. can be found at https://doi.org/10.1353/jwj.2018.0009 


\section{Marketing the Panpan in Japanese Popular Culture: \\ Youth, Sexuality, and Power}

In 1948, Women of the Night (Yoru no onnatachi), a film directed by Mizoguchi Kenji portraying streetwalkers in Osaka, became the first so-called "panpan film" (panpan eiga). Panpan was the derogatory expression commonly used in the postwar era to refer to streetwalkers and was usually_although not entirely accurately_identified with those soliciting foreign servicemen. Four months after the release of Women of the Night, another panpan film titled Gate of Flesh (Nikutai no mon, Makino Masahiro and Ozaki Masafusa), based on a novel by Tamura Taijirō, also achieved great commercial success. Film critic Futaba Jūzaburō $(1949,16)$ identified the panpan subgenre as one of the most outstanding features of domestic cinema production in 1948. Other similar productions followed, but partially due to the troubled relationship with the censorship bodies under the Supreme Commander for the Allied Powers (SCAP), the cycle of panpan films did not last very long. Naruse Mikio's White Beast (Shiroi yajū, 1950) and Ichikawa Kon's Nightshade Flower (Ieraishan, 1951), both featuring women giving up streetwalking, mark the end of the filmic fad for panpan. ${ }^{1}$ The popular yet problematic figure of the panpan constitutes, therefore, a critical trope in the imaginary of Japan under the Allied Occupation (1945-1952).

Women of the Night was widely promoted in the press, as evidenced by advertisements in the Yomiuri daily newspaper:

"They yell, kick, punch, fight over their territory. It's the beating of the women of the night. Depicting the bestiality and the sexual raw instincts of these fierce women!" (Yomiuri shinbun 1948a).

“Beautiful bodies! Warped adolescence!” (Yomiuri shinbun 1948b). 
"Cry at the heartrending condition of three sisters who fall into the danger of the night!" (Yomiuri shinbun 1948c).

These exclamations emphasized the titillating appeal of Women of the Night: the exploitative attraction of violence and sexuality, the dangers of youth, and the cathartic empathy towards heartbreaking stories. Deviant sexuality, youth, and women's relationships appear as major themes of other films and texts depicting the panpan in postwar popular culture. However, this article argues that the meanings and discourses articulated through the trope of the panpan were far from homogenous and often differed significantly from the social reality of streetwalkers.

Beyond cinema, the iconic panpan held a remarkable presence in the public opinion, ubiquitous in cultural and creative industries. In 1947, Tatsuno Takashi, prestigious essayist and professor of French Literature at Tokyo University, responded to the question "what is the newest (most democratic) thing" in Japan? with the reply: "the panpan" (Kamiya 2014, 79). This anecdote bears witness to a contemporaneous equation of "new" with "democratic" and the association of these terms with commercialized sex. What was probably seen as democratic is that, regardless of her social or ethnic background, the panpan moved freely and accessed commodities and spaces primarily restricted to the vanquisher. This image of liberation and social mobility contrasts with that of decay and disease evoked in the promotion of Women of the Night, suggesting the use of the trope of panpan by different groups to advance their own political agendas.

In comparing the lived experiences of panpan with their representations in various media, I will explore how the problematic social figure of the panpan was transformed into a marketable icon of popular culture, becoming an ambivalent signifier of discourses of youth, sexuality, and nation that appealed to different audiences. The analysis of the depictions of 
panpan in cinema is set against those in other high and lowbrow media texts, including literature, women's journals, and pulp short-lived publications known as "kasutori," bringing to the foreground the intertextual and intermedial nature of the figure of the panpan. Approached both as historical subjects and as images of a social category, the examination of the panpan reveals an interplay of fluid and overlapping structures of power.

The panpan has attracted much scholarly attention as an allegory of power relations between Japan and the United States (Molasky 1999, Kovner 2012, Saito 2014, Hirai 2014). In the field of cinema studies, she has often been approached through the categories of women and commercialized sex, and in relation to SCAP's censorship (Kamiya 2009, 2014; Hori 2012, Kim 2014, Kinoshita 2016, Saitō 2018). Kinoshita Chika (2016) and Saitō Ayako (2018) have challenged the reading of the panpan as a mere sexual metaphor of Japan being abused by the United States that stays trapped in gender binaries. Drawing on their work, I reject simplistic interpretations of the panpan as stigmatized victim or as heroic progressive figure. Instead, this article traces the nuances of her conflicting representations and the polarization of stereotypes crafted in the media to shed light on the interests underpinning such depictions. While previous studies of panpan and their social representation have focused tightly on gender, this article approaches the topic through the lens of youth to rethink the panpan as a compelling example of a young working female population, concomitant to the radical changes in terms of sexual mores, familial relations, and romance practices taking place in postwar Japan. Connecting the panpan to the rich symbolic load attached to conceptions, ideals, and fears about "youth" can reveal other allegorical functions performed by the fictional panpan beyond those related to commercialized sex. I will also suggest that images of the panpan fed into the postwar redefinition of youth as a social category, and that hence, the construction of "panpan" and "youth" informed each other. Finally, looking retrospectively from the surge of youth cultures in the mid-1950s, analyzing 
the representations of panpan as gendered youth locates the panpan within early discourses of postwar commodification and consumerism. For practical purposes, I consider youth primarily as those between fifteen and twenty-five years of age (based on Stoetzel 1955); however, it is worth noting that many sources referenced here use the label "youth" without specifying ages.

\section{Youth as Discursive Category and Conceptual Framework}

During the Occupation, "women" and "youth" became keywords in SCAP's agenda and promotion. Major reforms in terms of civil rights, labor, and education promised to liberate these social groups from the oppressive prewar system, and framed women and youth as foundational to the new democratic Japan (Koikari 1999). The establishment of the Bureau of Women and Youth (Fujin shōnen kyoku) in the Ministry of Labor in 1947, and the publication of non-official texts like The Return of Japan (Christian Deputation to Japan 1946), including a section titled "Women and Youth," bear witness to the common grouping of these two categories. However, this combination seems incongruent if we consider that "youth" refers to a temporary status (an age-based collective), while "women" is often conceptualized as a static category of identification.

To understand the significance of the combined category of women and youth, it is important to remember that labels are used by institutional systems to organize and monitor society and that they are always political, ingrained in relationships of power (Moncrieffe and Eyben 2007). Labels create meaning, impose boundaries, and involve assessments. In the case of Occupied Japan, what linked the two discursive categories of youth and women together was a narrative that posited both women and youth as not fully autonomous citizens and instead as weak subjects in need of protection and guidance. In this way they were simultaneously posited as fertile grounds for change and as loci of social concern. On a symbolic level, the categories of youth and woman effectively fitted the image of Japan that 
the United States aimed to construct: as a feminine other (referred to as "she" in English writings), and as an immature nation that is yet to become a proper member of the international community (Igarashi 2000, Shibusawa 2006). Moreover, because labels shape and are shaped by associations with certain activities, attitudes, spaces, and expectations (Moncrieffe and Eyben 2007), a systematized interpellation of youth and women across different fields worked to construct normative subjects and establish new markets of consumption for these recently enfranchised citizens. Analyzing how the panpan were positioned by social commentators and filmmakers as a non-normative expression of female youth can reveal the construction of these hegemonic, multi-layered practices of meaningmaking. Whilst not all panpan were young and not all were women, primary sources demonstrate that a significant number of them were so (Ōtani 1948, Takenaka and Sumiya eds. 1949, Minami 1949, McLelland 2012).

Empirically, "youth" is a slippery category. Since it is a cultural and historical construction, it lacks a fixed meaning and instead functions as a repository of myths, desires, and fears in the social imaginary (Bourdieu 1993, Honwana and de Boeck eds. 2005). Furthermore, youth is a liminal category caught between the similarly socially constructed conceptions of childhood and adulthood, making it difficult to delineate its boundaries. For practical reasons, I follow the definition provided by the French sociologist Jean Stoetzel (1955) in his study on the attitudes of youth in postwar Japan, commissioned by UNESCO in 1951. This study defined "youth" as people between fifteen and twenty-five years of age, and sometimes included those up to thirty. In 1945 there were approximately 13.3 million people between fifteen and twenty-four years old in Japan, constituting 18.45 percent of the total population. By 1952, youth amounted to almost 20 percent of the nation (Statistics Bureau b, n.d.). 
According to Stoetzel $(1955,67)$, marriage and the acquisition of social responsibilities, especially parenthood, were perceived as inaugurating "adulthood" and ending youth as a liminal state. In this regard, Stoetzel notes $(1955,67-70)$ that postwar men did not want to marry before twenty-six years of age (many not before thirty), while most women between twenty and twenty-four years of age were already wives and/or mothers. Thanks to Article 24 of the New Constitution (1947) and the revision of the Civil Code (1948), men and women above age sixteen were granted the right to freely choose spouses, but Stoetzel $(1955,67-8)$ notes that almost as important as choosing a partner was the freedom to choose when to marry and hence to postpone promotion to "adult status". Stoetzel uncritically defines "adulthood" in relation to the fulfillment of certain actions and roles that are considered hegemonic. If, following his argument, parenthood marked the end of "youth" then women tended to become "adults" earlier. Under this rationale, panpan could be said to remain associated with youth by rejecting monogamy, and often also marriage and motherhood; and yet, as autonomous workers, panpan complied with other normative requirements of the label of "adulthood."

A 1954 issue of the Research Institute of Social Psychology's magazine contended (translated in Daliot-Bul 2013, 42):

Until the defeat in the war, there was no period of youth (seinenki) in Japan. This is because people in that age bracket were not recognized as independent persons. Until they passed the military inspection, they were treated as children with no judgment; after passing the inspection, they were immediately treated as adults. [...] The proof is that after the war, once they earned the right to express their minds, teenagers (chīn'eijāzu) as an independent generation became a problem. 
This statement is problematic because it ignores important youth movements and moral panics around them occurring in the prewar era. Nevertheless, it reflects that the early postwar was perceived as a transitional period in which the label of youth was being redefined. As Michael Raine argues $(2002,3)$, youth was associated with a new democracy untainted by militarism, and yet simultaneously identified as a suspicious foreign cohort. The use of the English term "teenager" in the quotation appears to confirm the connection between youth and a foreign unsettling influence.

In the early postwar, the majority of youth lived in rural areas, but were increasingly migrating to the cities (Stoetzel 1955, 68-9; Statistics Bureau a, n.d.). In recalling the theaters filled with adolescent viewers, social critic Tsurumi Shunsuke noted that for the youth "film was the main form through which to express ideas and a forum in which the Japanese thought collectively" (as translated in Igarashi 2016, 25). The depiction of the experiences of young women living in the city could be one appeal of stories about panpan. The figure of the panpan could function as a reference against which to make sense of one's own experience of youth, and to learn how to navigate the unsettling environment of post-defeat Japan and its new ideas about gender, sexuality, labor, family, and consumption. Following this line of thought, the next section examines how the panpan were portrayed, explained, and evaluated in different platforms of public opinion, often in connection to the category of youth. The heterogeneous social reality of the panpan as a young female working population will be emphasized as a counterpoint to partial and biased representations that, I will argue, were utilized by different groups to advance their own understanding of postwar Japan.

\section{Conflicting Depictions of an Heterogeneous Collective}


The first panpan emerged among the homeless population of Tokyo, in the aftermath of defeat (Sanders 2012, 407). In March 1946, the closure of the Recreation and Amusement Association (RAA, Tokushi ian shisetsu kyōkai) fostered the increase of panpan around the country. Catering to American GIs, the RAA had been justified as a "floodwall of the flesh" (nikutai no bōhatei) against rape and miscegenation (Molasky 1999, 109), but it was closed down after only six months due to widespread venereal diseases (Kramm 2017). In December 1946, the government declared prostitution legal in delineated red-light districts (akasen chitai) in each city, and opened rehabilitation centers for streetwalkers, in collaboration with women's associations, which became a common setting of panpan films like Women of the Night and White Beast.

Because panpan worked independently, moved in and out of the sex market, and frequently changed their residence, it is hard to determine how many there were; estimates range between 50,000 and 70,000. ${ }^{2}$ Ethnographer Ōtani Susumu $(1948,64-72)$ claimed that 60 percent of panpan soliciting in Ueno Park (Tokyo) were between twenty and twenty-five years old, and another 20 percent between seventeen and twenty. ${ }^{3}$ Otani found that most panpan in Ueno, a neighbourhood where often orphans and homeless people took shelter, were uneducated women from a lower-class background. In contrast, in 1947 author Sakaguchi Ango $(1998,454)$ wrote that most of the panpan he interviewed had completed junior high school and came from "good families". ${ }^{4}$ Similarly, another ethnographic study claimed that one third of panpan had attended women's higher schools, while in the late 1940s only ten percent of all Japanese women did so (Sanders 2012, 419-20). Discrepancies among primary sources reveal a complex landscape of heterogeneous practices, profiles, and socio-economic backgrounds. They also suggest the selective use of information and narratives by different agents portraying panpan to confine these women into one coherent, manageable image, often justifying their deviant behavior based on social determinism. 
Whilst panpan are generally understood to be sex workers specializing in foreign customers, this was only one type of panpan, known as yōpan. Others catered exclusively Japanese men (wapan). According to a panpan named Tanaka Ayako (Minami 1949, 78), these women remained separated, working in different territories. Yōpan tended to work independently and were more harshly looked down upon by society, while those specializing in Japanese patrons sometimes depended on male gangs (gurentai). Tanaka was one of five panpan who participated in a round-table discussion (taidan) led by Minami Hiroshi in 1949 for the magazine Reconstruction (Kaizō). At the time, Minami was teaching at Japan Women's University and later became a prominent figure in the field of social psychology in Japan. Other university professors and authors (including Mishima Yukio) participated and conferred their prestige on the discussion.

The women interviewed by Sakaguchi identified themselves as "wapan." They dealt mainly with Japanese wealthy men from the countryside coming on business to Tokyo and frequently fixed appointments with patrons they already knew, instead of soliciting strangers in the street. These panpan also claimed to dress in sophisticated but discreet fashion (Sakaguchi 1998, 455-6). Their practices and looks, therefore, differed from the stereotypical aesthetics of the panpan: standing on the street with permanent wave hairstyles, pencil skirts and nylon panties, thick makeup, cigarettes, and chewing gum — all elements that implied a connection to American GIs. In this sense, Minami and Sakaguchi's publications showcase the diversity of panpan's lived realities at odds with simplified stereotypes that have been used to consolidate the image of the panpan and the GI as a metaphor for the occupied nation.

Testimonies of panpan in the press and on the radio framed them either as ignorant victims of war or as sexualized liberated women, but one must be wary of the potential manipulation of their accounts. The publications by Minami (1949) and Sakaguchi (1998), for instance, project an idealized image of the panpan, suggesting their reading of these women 
primarily as positive abstract symbols. The interviewees mention problems with drugs, security, and loneliness in their testimonies, but the texts highlight their independence within well-organized, supportive communities. Disavowing any potential stigma of the trade, these panpan state that they voluntarily undergo regular medical examinations and that they see prostitution as a temporary occupation, telling stories of acquaintances who have quit in order to get married or take other jobs. Sakaguchi $(1998,453-7)$ described them as "cheerful" (akarui), "free," and “natural.” He notes (1998, 457-8): "because they can establish themselves to work anywhere, freedom and strength has naturally soaked in them, and provided them with a personality of complete individualism." It is important to note that Sakaguchi was an exponent of the literary movement called Decadent School (Buraiha), which explored the aesthetic of decadence (daraku) as a political reaction to defeat (Wolfe 2001). Sakaguchi was close to Tamura Taijirō, author of the original novel of Gate of Flesh and representative of the "Literature of the Flesh" (nikutai bungaku) —as further discussed below. Both authors infantilize and sexualize panpan to utilize her as a signifier on which to project their ideas. Sakaguchi $(1998,458)$ saw the panpan as experiencing a transformation from their educated backgrounds into becoming primitive "natural beings," and went as far as to conclude: "When these women become natural persons as intelligent beings, Japan will truly become a culture state. Panpan are the symbol of the culture of the whole country."

In stark contrast, Women's Review (Fujin köron), the journal at the forefront of the women's movement advocating the abolition of prostitution, described panpan as "grotesque," "crazy," "morally and mentally deficient," and even "inhuman" (e.g. Tairamura and Nakano 1950, 34-5; Fujin kōron 1952; Uemura 1953, 45, Fujime 1997, 334-5). In 1950, columnists Tairamura Taiko and Nakano Yoshio deemed streetwalking a severe moral, social, and hygienic problem. They praised the political development of human rights in postwar Japan but wondered, "What kind of human rights should these women, who are satisfied with that 
kind of life, who do not have respect for their own life and livelihood, have?" (Tairamura and Nakano 1950, 36). Whereas Sakaguchi saw in the panpan a vehicle for postwar liberation and individualism, the anti-prostitution groups saw in her the antithesis of the democratic and healthy postwar Japan.

Other opinions, perhaps more focused on pragmatic concerns, existed between these two extremes. In 1948 the National Public Opinion Research Institute (Kokuritsu yoron chōsajo 1951) conducted a survey on people's views on prostitution by interviewing 1,372 adults over the age of twenty in the Kanto area. According to the results, prostitution was perceived as a "social evil" but one that satisfied a "certain social necessity" (1951, 5). 77 percent of the respondents believed that streetwalking should be prohibited, while 70 percent opposed the ban of brothels $(1951,4)$. Thus, beyond concerns of sexual morality, prostitution was broadly understood as a necessary sacrifice that dispensable members made for the wellbeing of society (or its privileged members) but one that should remain out of sight, preventing the contamination of public space. Panpan sold sex in the open, disrupting the public order and transgressing its divisions of labor, gender and class. This visibility had the unintended consequence of making panpan an important reference in normalizing public displays of courtship and romance at a time when heterosexual romance was being promoted in youth magazines and framed as an expression of democratization (McLelland 2012, 72, 88). Aware of this impact, panpan Fujisawa Nanao (Minami 1949, 86) lamented: “aren't high-school girls confusing this thing [selling sex] with democracy, or perhaps liberalism?" Panpan were also portrayed as influential fashion setters who were "as close as anyone in Japan might hope to get, in the flesh, to Hollywood" (Dower 1999, 137). ${ }^{5}$ Many were regular cinemagoers and avid buyers of American fashion magazines (Chazono 2014, 80 ), practices which informed their aesthetics and consequently impacted on youth culture. The potential wealth of the panpan and her connection to fashion is visually conveyed in 
White Beast, when we meet Keiko (Miura Mitsuko), a panpan forcibly taken to a rehabilitation center. A door opens and the camera cuts to a close-up of her high-heeled shoes, tilting up her stylish clothes until it sets in on a long-middle shot to appreciate Keiko's sophisticated fashion and pose through a soft-focus lens, evoking a model from a fashion magazine. Considering the development of youth cultures and fashion in the 1950s (DaliotBul 2013), I would suggest that, although in the late 1940s Japan was in a state of devastation and scarcity, the mechanisms that foster the commodification of young bodies and that craft identities through consumption were already set in motion. The dramatic increase of the young population, together with accelerated industrial recovery, the reinvigorated flourishing of popular media (particularly weekly periodicals), and contact with American and European commodities and information played a pivotal role in this process. With her exceptional financial independence, the panpan arguably constituted a forerunner of this new experience of youth tightly connected to consumerism.

Having access to high earnings was undoubtedly an attraction of the trade. Panpan earnings ranged from 15,000 to 50,000 yen (Sakaguchi 1998, 456; Tanaka 2012), at least four times the monthly salary of a female factory worker (Kovner 2012, 81; Sanders 2012, 416). Most of the panpan Minami (1949, 80-1) interviewed claimed to be the main wage earners for their families. Additionally, the fact that in the labor market women earned an average of 45 percent of male wages, and that many female workers had been dismissed after the war to create vacancies for the returned soldiers (Sanders 2012, 411) can partially explain the significant percentage of educated, middle-class women turning to the sex trade. Nevertheless, it is important to bear in mind other motivations that often featured in panpan's testimonies: the experience of rape (particularly among teenagers), escaping from troubled homes, "fascination" (akogare) for foreigners, and "curiosity" for the panpan's lifestyle (Minami 1949, 74-5; Takenaka and Sumiya eds. 1949, 204-20; Sakaguchi 1998; Hirai 2014: 
86-91).

Historian Tanaka Yuki $(2002,155)$ asserts: "[I]t is no exaggeration to say that it was not the textile, chemical, or other industries that were rehabilitating the immediate postwar Japanese economy but the sex industry, and that this came at the expense of the physical and psychological health of tens of thousands of Japanese sex workers." Tanaka's statement encapsulates the situation of the panpan as simultaneously powerful and powerless, and draws attention to the traumatic experience of these women. The next section argues that exploitative platforms of popular culture capitalized on the physical and psychological sacrifice of panpan to justify the commodification of the young female body.

\section{Panpan in Pulp Literature and Publications}

Because cinema was strictly controlled through pre- and postproduction censorship under the Civil Information and Education Division (CIE) and the Civil Censorship Department (CCD), examples from other media less comprehensively subject to censorship can help unfold the cultural meaning of the panpan. The analysis of pulp literature and publications reveals the high level of intertextuality underpinning the panpan's image, which will complicate the reading of her cinematic representation.

The so-called "panpan boom" (panpan buumu) was triggered by Tamura's novel, Gate of Flesh, published in March 1947 in the literature periodical Gathering Images (Gunzō), catapulting the author to fame. It tells the story of a gang of five panpan living in a burnt-out building under a strict code of behavior that prohibits any romantic involvement. The intrusion into their lives of war veteran Ibuki Shintarō shatters the balance of their community with tragic results. The novel attracted such attention and controversy that just five months later it was adapted into a stage play, which also became a sensational hit. The novel begins with the narrator's description of the body of nineteen-year-old Komasa no Sen, the leader of the gang: "When Sen is naked, her breasts still do not protrude much. For 
being nineteen years old, her skin does not have much glow, there is little fat around her muscles" (Tamura 1958, 184). Tamura posits Sen as youthful, not yet mature, merely pretending to be an adult, and thus draws a link between young body, subjectivity, and female sexuality.

For the members of literary groups like the Decadent School and the Literature of the Flesh, such as Tamura and Sakaguchi, the carnal body constituted the key to a new subjectivity opposed to the spiritual national body (kokutai) of the prewar militarist regime, which had repressed corporeal desires (Igarashi 2000, Slaymaker 2004, Wolfe 2001). This liberation is, however, gendered. In the novel and all cinematic adaptations of Gate of Flesh, war veteran Shintarō lives according to his instincts and desires, which entail the seduction and subjugation of women. He is characterized by his youthful, muscular body that offers an idealized, hyper-masculine subjectivity set against the crisis of masculinity the nation was experiencing due to defeat and occupation. In contrast, the panpan in the story use their bodies, but these are not connected to a liberating subjectivity because they remain committed to refusing romantic feelings or physical enjoyment in the sexual encounter. In this way, they claim, their souls remain chaste. When they do allow themselves to fall in love, as Maya does with Shintarō, they are physically and socially punished according to the gang's group consciousness (shüdan ishiki - a term often repeated in the novel), which resembles the prewar mindset of a spiritual collective body that must prevail over the individual. Thus, in Tamura's novel, while for men sexual experimentation and transgression become formative encounters in reaching adulthood, for women the fear of stigma hovers over their experience of sex during youth.

Under SCAP's banner of “women's liberation” (josei kaihō), the exhibition of women's bodies was framed as democratic emancipation from suffocating wartime morals, and "sexual liberation" (sei kaihō) materialized in "female nudity as public, paid 
entertainment and as a vehicle for constructing a masculinized notion of liberation" (Izbicki 1997, 111). Saito (2014) maintains that the traumatic experience of the Occupation was inscribed in the cinematic representation of women's bodies, which lay bare the contradictions of postwar democratization and the veiled continuities with the past (2014, 331). Expanding on this embodiment of postwar contradictions, I suggest that in the films and novel of Gate of Flesh the traumatized subjectivity and body of Japan, defeated and exhausted, was reified and split into two gendered bodies. Shintarō offered an ideal site of identification (primarily to reassure the male subject), while female characters served as catharsis for the experience of loss and vulnerability while supporting the illusion of masculine power. This gendered split in characterization, however, does not necessarily mean a gender/sex split in audiences; spectators could simultaneously enjoy the fantasy of domination and that of victimhood seeking to come to terms with their bewildering perception of the past and the present.

The stage play of Gate of Flesh was launched in 1947 in the Teitoza Theater in Shinjuku, the same venue that inaugurated the "picture-frame nude show" (gakubuchi nūdo $s h \bar{o}$ ) featuring scantily dressed women posing inside large-scale picture frames. The panpan play was staged in Tokyo alone more than seven hundred times in a year (Kamiya 2009, 154) and ran over three years (Saito 2014, 335). It became a great success largely due to the provocative costumes and cunning sexual references, the climax scene being the stripping and beating of a panpan by the others (Saito 2014, 335). Many types of erotic shows emerged during these years, and the display of the female body was adapted to different audiences and formats, from striptease (which opened in Asakusa in 1948) to more socially acceptable practices like the American-style beauty contests celebrated since 1947 (Bardsley 2013). In economic terms, this meant a vast range of relatively well-paid job opportunities for young women: as models, dancers, waitresses, and sex workers, amongst others. The reinvigorated 
"service industry," or what I call "female body industries," meant unprecedented practical power and autonomy for young women, but also grounded the notion of the female body and sexuality as marketable products. Because the female body industries indirectly influenced others, such as hospitality and fashion industries, they cannot be separated from the postwar development of consumer capitalism and of certain types of corporate entertainment. The panpan and their aesthetics played an important role in shaping this commodification of the young female body.

John W. Dower $(1999,122)$ identifies the panpan as a chief component of the "cultures of defeat," which also included the black market and the pulp escapist culture known as "kasutori." These interconnected cultures of defeat emerged essentially from urban environments and existed, by choice or necessity, in the fringes of whatever remained of normative socioeconomic structures, performed unabashedly in public spaces. Kasutori publications became, therefore, a crucial site for the construction, consumption, and dissemination of the image of the panpan. The name comes from kasutori shōchu, a strong, cheap, and illegal liquor made of potatoes and industrial alcohol (kasutori means dregs) that was popular on the black market and among artists. Addressing primarily male audiences, these publications dealt with erotica, sensationalistic crimes, and exposés. The female body was a highly commodified object of visual pleasure at the center of spectacles of sex and violence. Some kasutori magazines discussed issues of sexual health and "sexual techniques," and panpan sometimes featured as experts in this new body of knowledge (McLelland 2012, 78-85), similar to how Sakaguchi (1998) framed his interviewees. However, kasutori magazines also frequently included morbid stories about panpan's venereal diseases and their traumatic experiences of forced medical examinations (Yamamoto 1998, 161-3); hence the panpan's image in relation to sexual health was contradictory. 
Kasutori magazines drew a connection between sex, freedom, decadence, and Western culture in the display of semi-naked young Caucasian women and the use of borrowed English titles, such as Venus and Pinup (written in both English and Japanese). For example, the cover of a 1947 issue of Crime Readings (Hanzai yomimono) features a drawing of a topless blonde woman looking straight at the viewer while she winks an eye and holds up a glass of champagne (reproduced in Yamamoto 1998, 313). The cover for Pinup August 1948, features woman in red skirt and bra, with red lipstick and a permanent wave hairstyle with a broad quiff that recalls the stereotypical panpan look. I suggest that these images offered an opportunity for Japanese men to observe, commodify, and imagine possessing the vanquishers' women. Moreover, in their sartorial similarity, the panpan functioned as an intermediate, polluted subject on which to project the anxiety and excitement brought by the foreign regime. Kasutori newspapers frequently depicted panpan gang fights and punishment beatings (rinchi in Japanese, from the English "lynch"). For example, the cover of Floating World Newspaper (Ukiyo shinbun) February 1, 1948 features a drawing of a panpan in a tight dress, lashing with a belt a kimono-clad woman lying on the floor. A group of eleven women surround them, glaring down at the woman. As discussed below, similar beating scenes became a convention of later panpan films. Acknowledging the influence of kasutori culture, Kitasawa Toshiko, a twenty-seven-year-old panpan, underscored that these kinds of beatings rarely happened within the panpan communities and were just a stereotype fabricated in the media (Minami 1949, 78). While it is difficult to ascertain common practices among panpan, these examples bear witness to the substantial impact of kasutori culture on the popular imaginary of the panpan.

\section{Sex and Violence in Panpan Films}


One of the most arousing scenes in White Beast occurs when Keiko attempts to seduce the director of the rehabilitation center. Shot in soft focus, Keiko lies on a bed and her torso in shown in a middle-close-up in a highly sensual pose with eyes and lips half-closed. She then lifts her left hand to caress her right breast over her blouse. Likewise, in the 1948 film of Gate of Flesh, Sen tries to seduce a priest from a nearby church whom she mistakes for a client. After he leaves, she lays down alone caressing her breasts over her clothes. The existence of these similar scenes hints at the limits of the erotic depiction set by censorship or self-censorship within the studio system, and at the experimental stage of the new regime in representing sexuality on screen. This restrained cinematic depiction stands in stark contrast to kasutori publications and Tamura's novel. When Machiko is beaten by the other panpan, Tamura $(1958,198-9)$ vividly describes her "covetous buttocks" being brutally beaten, "swelling before one's eyes, and the muscles in the whipped area becoming marked as if painted with crimson paint." The sexual act between Maya and Shintarō is both graphically violent and erotically charged, while Maya's sexual arousal (and possible orgasm) is described as follows: "Her body was shaking as if charged with electricity, her hips throbbing with a seducement beyond description" (Tamura 1958, 213).

Before its release, the 1948 film adaptation aroused great expectations of titillation. Provocative still images of the film were published in The Movie Times (Kinema junpo 1948b, n.p.): Sen (played by Todoroki Yukiko) appears lying on her back with an open shirt that creates a plunging neckline and accentuates the shape of her breasts. In another photograph, Maya (played by Tsukioka Chiaki) lies prone on the floor; her torso is naked while her breasts are partly hidden. Her torn and wrinkled skirt reveals her calves and part of her thighs while the spotlight enhances her white exposed skin. Yet, in the actual film, sexual references are scarce and the naked female body is not exposed. The original story is conspicuously twisted to avoid compromising scenes and, hence, the sexual encounters between Shintarō 
and senior panpan Machiko and later with Maya are omitted, although pivotal to the novel. The transformation of the character of Maya is particularly remarkable as it lays bare the ideological manipulation behind the film.

While in the novel eighteen-year-old Maya is the pragmatic co-leader of the gang, in the film she is an innocent, curious girl who wishes to join the panpan group so as not to be lonely. Her experience of prostitution is depicted as terrifying, divested of any eroticism or excitement. During her first encounter with a customer, Maya screams, rejecting the man. The camera cuts to Maya running desperately in the streets, crying and holding a wad of bills tightly in her hand. Shot in fast motion and under a hard flickering light, reminiscent of German expressionist cinema, Maya's body is alternatively strongly illuminated and reduced to a dark silhouette; first in a long shot, and then in a quickly edited sequence, gradually tightening the frame while increasing the length of the moments of darkness, until the scene finishes with the black silhouette of Maya's close-up as she continues to run frenetically. This scene magnificently evokes a metaphorical opposition between the "bright" chaste girl and the woman who falls into moral darkness (note that panpan were referred to as "women of the dark"-yami no onna).

Gate of Flesh was a box-office success (Kamiya 2009, 157) but some film critics condemned the film as erotic sensationalism, and others found it full of clichés resulting in a far-fetched story (Kinema junpō 1948b, Kinema junpō 1948c; Futaba 1949, 17). In contrast, columnists Tairamura and Nakano $(1950,35)$ discussing the actuality of streetwalking in Women's Review, praised the film for its realistic depiction of streetwalking and of the panpan's "short temper and terrorism" (terorizumu). This article demonstrates that, at a time when heated debates around prostitution, abortion, and the sexual mores of youth were occurring in the media and other public forums, cinema was quoted as a legitimate reference 
to panpan's social reality. Moreover, mixed critical reviews show that different audiences picked up on different elements of the plot to advance their own ideological agenda.

Mizoguchi's Women of the Night was also a great commercial success. It ranked third in The Movie Times' best ten films of 1948 and became the highest grossing film to date, with ticket sales of 12,350.000 yen (Kinoshita 2016, 429). The story revolves around the lives of three women: Fusako (played by Tanaka Kinuyo), a war widow who becomes a panpan after being abandoned by her lover; Natsuko (played by Takasugi Sanae), Fusako’s younger sister, always dressed in Western fashion and working in a dancehall, who takes up with her sister's lover; and Kumiko (played by Tsunoda Tomie), Fusako's sister in law and the youngest of the three. Mizoguchi's film is quite moderate in the exposure of the female body but, unlike Gate of Flesh, it portrays sexual violence in a harrowing way through the character of Kumiko. Kumiko is introduced as a naïve teenager dazzled by the dancehalls and Natsuko's expensive Western clothes. To escape her dictatorial brother, Kumiko runs away from home and is deceived by a teenager who takes her to a small inn. In a long take the camera makes us witness Kumiko's rape. After being forced to drink alcohol, Kumiko falls almost unconscious on the floor; her weakened body is illuminated while the boy, shown slightly further left, remains in the shade. As he attacks her, Kumiko backs up vainly. Struggling, they crawl towards the far right of the frame, while the camera, as an impassive witness, moves to keep the action centered in the frame. Eventually, the rape takes place hidden from the viewers behind boxes and piled up cushions, but Kumiko's terrified voice makes the violence of this scene devastating.

Scenes "dealing with or approving the subjugation or degradation of women" were prohibited by censorship as reminiscent of pre-defeat "feudalistic" gender ideologies (Hirano 1992, 44). While CIE ordered the deletion of the scene of the prostitutes" "lynching" from the synopsis of Gate of Flesh (Hirano 1992, 283), all panpan films include beating scenes. The 
final scene of Women of the Night is, in fact, very similar to the drawing from Floating World Newspaper discussed earlier. Considering that kasutori publications had emerged in 1946, their impact on shaping the conventions of the panpan subgenre is undeniable. Despite censorship, in the films the representation of violence is much more graphic than that of sex, especially woman-on-woman violence, which hints at the censors' gender bias. While Kumiko's rape is hidden from the camera, during the beating scene, her clothes are ripped off one by one by the female assailants until Kumiko's body is left exposed.

Public opinion also seemed concerned with the moral responsibility of the cinema industry. Several reviews criticized Women of the Night as sensationalist for appealing to the audience's curiosity about exploitation while others praised its realism (Seki 1948; Kinema junpō 1948a). According to a review by Seki Chikoda $(1948,11)$, "For all those good children that may find themselves in the danger of falling into becoming a panpan, the film Women of the Night should leave a strong and deep impression of "morality" (moraru)" but, according to Seki, it fails to do so. Another review in The Movie Times explains that youths in Kyoto were banned from watching the film for fear that the rape scene could incite sexual crimes (Kinema junpō 1948a, 27). Thus, cinema was referenced as documenting the sex trade and simultaneously evaluated for its impact on sexual mores, especially those of the youth. From a marketing perspective, this type of news probably increased the popularity of the film and attracted more curious spectators. In experimenting with the new freedom to portray sexuality, the cinema industry popularized a synergistic interaction of sex and violence, which would have great influence on the national cinema of the following decades. This obscuring of the distinctions between liberation and exploitation benefited SCAP as it served as an escape valve for social frustration and simultaneously as a means to contain women socially and sexually. 
Both Gate of Flesh and Women of the Night depict women's experiences outside the institutions of marriage and the family as highly dangerous and doomed to failure. Kim Bokyoung $(2014,57-70)$ convincingly argues that the three women of Mizoguchi's film undergo a "crossing" from their initial position as "respectable" women to becoming prostitutes, or being treated as such. This is visually and aurally underscored in the opening sequence through the tropes of railroads, trains, and crosswalks. Kim reads the film as exposing the artificiality of the dichotomy between "respectable woman" and "prostitute" based on which the criminalization of the panpan was justified; and I would add other possible readings. In Gate of Flesh, Women of the Night, and White Beast the panpan characters are rejected by men they seek to solicit or seduce, suggesting the films' moral condemnation of the women who are deemed deviant, while these virtuous men stand for society's morality. The downfall of the protagonists can also be read as a warning for "respectable" women seeking sexual and economic autonomy (Hori 2002, 50), an approach frequently present in Women's Review. For example, a short story written for the journal by playwright Kikuda Kazuo (1950) tells of a young woman eager for new experiences who eventually finds herself trapped in prostitution. Furthermore, because "curiosity" and "admiration" were commonly cited as reasons for becoming a panpan in printed media and surveys, I suggest that the panpan films offered a safe fantasy of the underground world. Women of the Night, for instance, was shot in numerous locations of Osaka, including Tobita and Tennoji, ${ }^{6}$ areas known for their relation to the sex trade and hence probably unseen by many "respectable women" in reality. These films thus provided spectators with excitement and adventure, while ultimately reinforcing the security of their normative positions. Through themes of sexuality and violence, the panpan was constructed as at once powerful and disempowered, as threat to and victim of the system. 
From a different perspective, the character of Kumiko establishes a connection between decadent sexuality and Western culture, similar to that found in kasutori magazines. Since the rape pushes Kumiko into prostitution, her attraction towards the Westernized material luxury she sees in Natsuko's lifestyle is indirectly underscored as connected to Kumiko's tragic fate, because this is partially the reason why she decides to roam alone in the city. Kumiko serves as a metaphor of post-defeat Japan, trapped between the oppressive patriarchal authority of the prewar (her brother) and the glittering illusion of freedom and prosperity brought by the American Occupation (Natsuko). Both options are deemed equally exploitative of and oppressive for women Moreover, the characterization of Tanaka as war widow-turned-panpan, which was also a recurrent character in kasutori publications, can be read as subtle criticism of the Occupation for its denial of financial support for widows and its failure in truly empowering women and youth.

SCAP was clearly aware of the potential of panpan films to convey contempt against the Occupation. The guidelines of the Motion Picture Unit classified the representation of prostitutes under the category of "antisocial behavior" and required films to show "that crime does not pay and that justice always wins in the end" (Hirano 1992, 74-75). Regarding Gate of Flesh, the CIE required the filmmakers to "tone down the cynicism of streetwalkers and useless emphasis on money in the revised script" (Hirano 1992, 283) and to delete scenes of soliciting and those depicting "obscene" poses (Kinoshita 2016, 424). The depiction on screen of the Allied Forces and their "fraternization" with Japanese people was strictly prohibited, and hence all panpan in the films cater to Japanese men. On the one hand, the censor's guidelines worked to prevent the level of exploitation found in the panpan's representation in kasutori culture, and to call attention to the significant involvement of Japanese men in the sex trade during the Occupation era. On the other, censorship systematically downplayed panpan's ability to occupy public space and manage her own 
sexuality. The potential eroticism and political criticism of the panpan films lay primarily in the audiences' ability to decode symbolic metaphors, absences, and intertextual references to other more explicit creative industries. These films presented the panpan as a symbol of a nation losing itself in the attempt to reach a new prosperity and used her contradictory image to underscore the necessity for female chastity. The final section demonstrates that the conception of youth was essential in the dramatization of this narrative.

\section{Hope for the New Generation}

Censors demanded that panpan films stressed the rehabilitation of prostitutes (Kinoshita 2016, Saitō 2018), but I argue that this was represented almost exclusively in relation to the up-coming generation. Younger characters and infants evoke the regeneration of the nation and the possibility of a bright new era. In White Beast, Keiko's final resolution to change her lifestyle comes after a physical and emotional breakdown, as she walks towards the sunrise listening to the first cry of a baby born to Mari, a younger inmate of the panpans' rehabilitation center. In Women of the Night, young Kumiko is ultimately saved by her sisterin-law, Fusako. As the women meet by chance, Fusako learns that Kumiko has become a panpan and violently scolds the girl in front of her gang. Then the camera follows Fusako as she sits down underneath a stained-glass window of the Virgin and Child, the only remains of the ruined church where the scene takes place. Kumiko, also inconsolably crying, enters the frame from the right crawling towards Fusako and hugs her lap. The two women are now determined to quit prostitution, but a group of panpan immobilizes Fusako while one lashes her with a belt all around her body and face and another one beats her with a cudgel. The rest of the women take sides and a crowded panpan fight begins, which eventually enables Fusako and Kumiko to escape. 
Likewise, in Gate of Flesh the elder panpan's sacrifice for the youngest is shown with religious overtones (Kamiya 2009). After beating up Maya for becoming romantically involved with Shintarō, Sen lies on the floor with her arms spread, full of uncertainty, regret, and sadness. The frame of a window casts a shadow over her figure in the shape of a cross, unequivocally evoking a crucifixion. Sen's symbolic crucifixion alludes to the many female victims of war and defeat who cannot be saved and will become martyrs to history. Meanwhile, the cheerful Maya suggests that there is hope if society saves the young from total decadence. Elder panpan cannot escape their stigma and tragic fate, while younger panpan are naïve, systematically victimized and ultimately saved. The past cannot be changed, but one can fight for the future. From a political standpoint, this optimistic script was useful to both Japanese and American authorities because it projected responsibility towards the future and turned its back to the problematic past.

The new generation, however, needed guidance. In the 1948 film, Shintarō proposes to Maya, promising to get a job to provide for them both — in stark contrast with the ending of the book. Soon after in the film, Shintarō is arrested by the police (emphasizing the ultimate victory of justice and law as prescribed by CIE), but before he is taken away, he asks the priest to take care of Maya until his return. Shintarō's transgressive nihilism is ultimately rendered an outdated and futile mode of masculinity in comparison to the priest, who embodies a positive and democratic alternative. I would argue that the priest represents the Occupation and serves as mediator and guide for the young couple, who symbolize postwar Japan. Visual elements, such as the priest wearing a New York Yankees cap and offering chocolate to Sen seem to underline this association. More importantly, this ending suggests that regeneration entails constructing new structures of justice and restoring some hierarchies of power shaken by war, especially those of marriage and patriarchal power. The young 
panpan represents postwar Japan's fall into decadence but also serves as an image of hope for the future.

The films additionally introduce female characters antagonistic to the panpan as positive models to young female audiences. Gate of Flesh features a policewoman (played by Sayo Fukuko), who is not present in the novel. An old friend of Sen, she tries to convince her to quit prostitution, claiming they are both the same but have chosen different paths to achieve independence as women. Similarly, in White Beast, Dr. Nakahara (played by Iino Kimiko) is a fashionable and independent woman who arouses admiration and attraction among the inmates. In contrast with how Keiko was visually introduced (static and inspected by the camera's tilt), Dr. Nakahara makes her first appearance in a medium-long shot as she opens a door and walks towards the camera while talking to the male director of the center: she is a dynamic subject, not just an object to observe. Set in opposition to these modern working women who epitomize SCAP's gender reforms, the panpan are cast as throwback characters attached to prewar mentalities and ideologies. Furthermore, as war is highlighted in the films as the main cause of women's entering the sex trade after losing their families and homes, their sexual exploitation is portrayed as connected to the past, not the presentdespite historical evidence of the increase of streetwalking during the Occupation.

As community and familial structures collapsed in the aftermath of defeat, the figure of the panpan in cinema, popular novels, women's journals, and kasutori culture was drawn from abiding myths regarding youth and femininity. Overlapping and contradictory narratives provided a flexible context in which to negotiate a continuity with the past, while fulfilling the requirements and expectations of the future. Cinema was among the most restrained cultural industries in its depiction of the panpan. Under SCAP's censorship, the cinema industry aimed to adapt the contested social reality of the panpan into a coherent, manageable narrative that could be marketed as a transmedia commodity. In the panpan films there is no 
trace of the liberated and natural panpan praised by Sakaguchi Ango, nor of the despicable criminals presented by anti-prostitution groups. Films like Gate of Flesh and Women of the Night downplay the panpan's financial autonomy and their impact on adjacent industries, and silence their sexual health practices. Film censorship prevented, to a certain extent, the total commodification of the female body, but also partially suppressed the panpan's subversiveness; yet, the films relied on intertextual and intermedial references to provide simultaneously exploitative pleasure and a fantasy of victimhood for multiple audiences. Presenting the panpan as a remnant of a cruel regime that had been overthrown, and dramatizing the narrative of young victims who must be saved advanced the official, desirable version of recent history. The panpan films thus became a reflexive and cathartic site for a national audience cast in the mode of a juvenile subject who had suddenly lost the referential parental authority.

\section{Works Cited}

Bardsley, Jan. 2013. "Miss Japan on the Global Stage: The Journey of Itō Kinuko.” In Modern Girls on the Go: Gender, Mobility, and Labor in Japan, edited by Alisa Freedman, Laura Miller, and Chris Yano, 169-192. Palo Alto: Stanford University Press.

Bourdieu, Pierre. 1993. Sociology in Question. Translated by Richard Nice. London: Sage Publications.

Chazono, Toshimi. 2014. Panpan to ha dare nonoka (Who are the panpan?). Tokyo: Impakuto shuppankai.

Christian Deputation to Japan (D. Horton, J. C. Baker, L. J. Shafer, and W. W. Van Kirk). 1946. The Return to Japan: Report. New York: Pub. for Federal Council of the Churches of Christ in America and Foreign Missions Conference of North America by Friendship Press.

Daliot-Bul, Michal. 2013. "The Formation of 'Youth' as a Social Category in Pre-1970s Japan: A Forgotten Chapter of Japanese Postwar Youth Countercultures.” Social Science Japan Journal 17, no. 1: 41-58.

Dower, John W. 1999. Embracing Defeat: Japan in the Aftermath of World War II. London: Penguin.

Fujime, Yuki. 1997. Sei no rekishigaku (The Historiography of Sex). Tokyo: Fuji Shuppan. 
. 1952. "Panpan to bōeki" (Panpan and International Trade). Fujin kōron

(Women's Review). October: 27.

Futaba, Jūzaburō. 1949. "Nihon eiga kessan" (Closing Accounts on Japanese Cinema). Eiga geijutsu (Film Art). February: 15-19.

Hirai, Kazuko. 2014. Nihon senryō to jendā: Beigun, bai-baishun to Nihon joseitachi (The Occupation of Japan and Gender: American Military, Prostitution, and Japanese Women). Tokyo: Yūshisha.

Hirano, Kyoko. 1992. Mr. Smith Goes to Tokyo: The Japanese Cinema under the American Occupation, 1945-1952. Washington, D.C: Smithsonian Institute.

Honwana, Alcinda M., and Filip de Boeck, eds. 2005. Makers \& Breakers: Children \& Youth in Postcolonial Africa. Trenton, NJ: Africa World Press.

Hori, Hikari. 2002. "Eiga wo miru koto to kataru koto - Mizoguchi Kenji [Yoru no onna tachi] (1948 nen) wo meguru hyōron, jendā, kankyaku" (Seeing and Talking Film: Criticism, Gender and Spectatorship of Mizoguchi Kenji's 'Women of the Night' [1948]). Eizo gaku (Film Studies) 68: 47-66.

Ichikawa, Kon, director. 1951. Ieraishan (Nightshade Flower). Shintōhō. No DVD distribution.

Igarashi, Yoshikuni. 2000. Bodies of Memory: Narratives of War in Postwar Japanese Culture, 1945-1970. Princeton: Princeton University Press.

. 2016. Homecomings: The Belated Return of Japan's Lost Soldiers. New York:

Columbia University Press.

Izbicki, Joanne. 1997. "The Shape of Freedom: The Female Body in Post-Surrender Japanese Cinema”. In U.S.-Japan Women's Journal, English Supplement, Special Issue: Gender and Imperialism, edited by Brett de Bary, no.12: 109-153.

Kamiya, Makiko. 2009. "Senryōki 'panpan eiga' no poritikkusu - 1948 nen no kikai shikake no kami" (The Politics of the Panpan Film under the Occupation: 1948's Deux ex Machina). In Senryōka no eiga - kaihō to ken'etsu (Cinema under the Occupation: Liberation and Censorship), edited by Iwamoto Kenji, 151-186. Tokyo: Shinwasha.

. 2014. "Sei naru onnatachi: senryō shiteki bunha kara hahamono eiga wo yominaosu" (Sacred Women: Revisiting the 'Mother Film' from the Historical Context of the Occupation). Engeki kenkyū: Engeki hakubutsukan kiyō (Theater Studies: Bulletin of the Theater Museum). Vol. 37: 65-82.

Kikuda, Kazuo. 1950. “Midori hoteru” (Hotel Midori). Fujin kōron (Women's Review). August: 106-119.

Kim, Bokyoung. 2014. Sengo minshushugi to josei eiga: Amerika senryōki no Mizoguchi to $<$ josei kaihō> (Postwar democracy and women's film: The Mizoguchi of the American Occupation and 'women's liberation'). Ph.D. dissertation. University of Tsukuba. 
Kinema junpō. 1948a. "Yoru no onnatachi" (Women of the Night). Kinema junpō (The Movie Times). Early July: 27.

Early July: n.p.

1948b. "Nikutai no mon" (Gate of Flesh). Kinema junpō (The Movie Times). . 1948c. "Nikutai no mon" (Gate of Flesh). Kinema junpō (The Movie Times).

Late September: 38-39.

Kinoshita, Chika. 2016. Mizoguchi Kenji ron: Eiga no bigaku to seijigaku (On Mizoguchi Kenji: The Aesthetics and Politics of Film). Tokyo: Hōsei daigaku shuppankyoku.

Koikari, Mire. 1999. "Rethinking Gender and Power in the U.S. Occupation of Japan, 19451952." Gender and History 11, no. 2: 313-335.

Kokuritsu yoron chōsajo. 1951. The Japanese People Look at Prostitution. Tokyo: National Public Opinion Research Institute.

Kovner, Sarah. 2012. Occupying Power: Sex Workers and Servicemen in Postwar Japan. Stanford: Stanford University Press.

Kramm, Robert. 2017. Sanitized Sex: Regulating Prostitution, Venereal Disease, and Intimacy in Occupied Japan, 1945-1952. Oakland: University of California Press.

Makino, Masahiro and Ozaki Masafusa, directors. 1948. Nikutai no mon (Gate of Flesh). Tōhō. No DVD distribution.

McLelland, Mark. 2012. Love, Sex, and Democracy in Japan During the American Occupation. New York: Palgrave Macmillan.

Minami, Hiroshi. 1949. "Zadankai panpan no sekai” (Roundtable Discussion: The World of Panpan). Kaizō (Reconstruction). December: 74-87.

Mizoguchi, Kenji, director. 1948. Yoru no onnatachi (Women of the Night). New York: Criterion Collection. DVD.

Molasky, Michael S. 1999. The American Occupation of Japan and Okinawa: Literature and Memory. London: Routledge.

Moncrieffe, Joy and Rosalind Eyben. 2007. The Power of Labelling: How People are Categorized and Why it Matters. London: Earthscan.

Naruse, Mikio, director.1950. Shiroi yajū (White Beast). Tanaka Productions. No DVD distribution.

Onchi, Hideo, director. 1964. Jotai (The Call of Flesh). Tōhō. No DVD distribution. Ōtani, Susumu. 1948. Ikite iru: Ueno chikadō no seitai (Alive: The Ecology of Ueno 
Underground). Tokyo. Yūjinsha.

Pin'appu. 1948. Magazine’s cover. Pin'appu (Pinup). August.

Raine, Michael J. 2002. Youth, Body, and Subjectivity in the Japanese Cinema, 1955-1960. Ph.D. dissertation. University of Iowa.

Saito, Ayako. 2014. "Occupation and Memory: The Representation of Woman's Body in Postwar Japanese Cinema." In The Oxford Handbook of Japanese Cinema, edited by Daisuke Miyao, 327-362. Oxford: Oxford University Press.

. 2018. "Senryōki kara posuto senryōki eiga ni okeru < panpan> hyōshō ga toikakeru" (An enquiry into the representation of the panpan from Occupation films to postOccupation films). In Haisen to senryo (Defeat and Occupation), edited by Tsuboi Hideo, 3388. Tokyo: Rinsen shoten.

Sakaguchi, Ango. [1947] 1998. "Panpan gāru” (Panpan Girls). In Sakaguchi Ango zenshū (Sakaguchi Ango Complete Works). Vol. 5, edited by Sakaguchi Tsunao, 453-458. Tokyo: Chikuma shobō.

Sanders, Holly. 2012. "Panpan: Streetwalking in Occupied Japan." Pacific Historical Review 81, no.3: 404-431.

Seki, Chiyoda. 1948. "Aku no sanbi ni ochiiruna" (Do not Fall in the Glorification of Evil). Kinema junpō. (The Movie Times). Late July: 11.

Shibusawa, Naoko. 2006. America's Geisha Ally: Reimagining the Japanese Enemy. Cambridge, Mass.: Harvard University Press.

Slaymaker, Douglas. 2004. The Body in Postwar Japanese Fiction. New York: Routledge Curzon.

Statistics Bureau of Japan a (2006?). "Population of Cities (1920-2005)."

http://www.stat.go.jp/english/data/chouki/02.htm (accessed January 24, 2018).

. b (2010?). "Population by Five-year Age Groups and Sex (Population

Estimates) (1920-2009)." http://www.stat.go.jp/english/data/chouki/02.htm (accessed January 24, 2018).

Stoetzel, Jean. 1955. Without the Chrysanthemum and the Sword: A Study of the Attitudes of Youth in Post-War Japan. New York: Columbia University Press.

Tairamura, Taiko and Nakano Yoshio. 1950. “Tōkyō no 25 ji” (Tokyo's 25 th Hour). Fujin kōron (Women's Review). November: 30-39.

Takenaka, Katsuo and Sumiya Etsuji, eds. 1949. Gaishō: Jittai to sono shuki (Streetwalking: Actual Situation and Notes). Tokyo: Yūkōsha.

Tamura, Taijirō. [1947] 1958. "Nikutai no mon" (Gate of Flesh). In Nikutai no mon, Nikutai no akuma (Gate of Flesh, Devil of Flesh), 183-219. Tokyo: Shinchō. 
Tanaka, Masakazu. 2012. "The Sexual Contact Zone in Occupied Japan: Discourses on Japanese Prostitutes or Panpan for U.S. Military Servicemen." Intersections: Gender and Sexuality in Asia and the Pacific 31. http://intersections.anu.edu.au/issue31/tanaka.htm (accessed January 6, 2014).

Tanaka, Yuki. 2002. Japan's Comfort Women: Sexual Slavery and Prostitution during World War II and the U.S. Occupation. London: Routledge.

Uemura, Tamaki. 1953. "Baishōfu no inai sekai wo" (Towards a World without Prostitutes). Fujin kōron (Women's Review). April: 44-47.

Ukiyo shinbun. 1948. Newspaper's cover. Ukiyo shinbun (Floating World Newspaper). February 1.

Wolfe, Alan. 2001. "From Pearls to Swine: Sakaguchi Ango and the Humanity of Decadence." In War, Occupation, and Creativity: Japan and East Asia, 1920-1960, edited by Marlen J. Mayo and J. Thomas Rimer with Eleanor Kerkham, 360-379. Honolulu: University of Hawai'i Press.

Yamamoto, Akira. 1998. Kasutori zasshi kenkyū - shinboru ni miru füzokushi (Research on Kasutori Magazines: The Water Trade through Symbols). Tokyo: Chūōkōronsha.

Yomiuri shinbun. 1948a. "Yoru no onnatachi" (Women of the Night). Advertisement. Yomiuri shinbun (Yomiuri newspaper). May 13: 2.

. 1948b. "Yoru no onnatachi" (Women of the Night). Advertisement. Yomiuri shinbun (Yomiuri newspaper). May 16: 2.

. 1948c. "Yoru no onnatachi" (Women of the Night). Advertisement. Yomiuri shinbun (Yomiuri newspaper). May 19: 2.

\footnotetext{
${ }^{1}$ Other panpan films were planned but delayed, ultimately not produced, or severely changed due to censorship (Kamiya 2009, 2014).

${ }^{2}$ Sanders $(2012,406)$ notes 50,000 panpan in 1950, decreasing to 30,000 in 1957; McLelland $(2012,72)$ estimates a peak of 70,000 during the Occupation.

${ }^{3}$ Chazono $(2014,111,169)$ and McLelland $(2012,71)$ estimate that the majority were teenagers or in their early twenties.

${ }^{4}$ The article was originally published in the magazine All Readings (Ooru yomimono, October 1 $\left.1^{\text {st }}, 1947\right)$, and reproduced in Sakaguchi Ango Complete Works (1998).

${ }^{5}$ See also McLelland (2012, 86-88), Chazono $(2014,80)$.
} 
${ }^{6}$ On the relationship between space, censorship, and body politics in Women of the Night see Saitō (2018). 